\title{
Genetic Characterisation and Comparison of Three Human Coronaviruses (HKU1, OC43, 229E) from Patients and Bovine Coronavirus (BCoV) from Cattle with Respiratory Disease in Slovenia
}

\author{
Monika Jevšnik Virant ${ }^{1}$, Danijela Černe ${ }^{2}$, Miroslav Petrovec ${ }^{1}$, Tomislav Paller $^{3}$ and Ivan Toplak $^{2, *(D)}$ \\ 1 Institute of Microbiology and Immunology, Faculty of Medicine, University of Ljubljana, Zaloška 4, \\ 1000 Ljubljana, Slovenia; monika.jevsnik@mf.uni-lj.si (M.J.V.); mirc.petrovec@mf.uni-lj.si (M.P.) \\ 2 Virology Unit, Institute of Microbiology and Parasitology, Veterinary Faculty, University of Ljubljana, \\ Gerbičeva 60, 1115 Ljubljana, Slovenia; danijela.cerne@vf.uni-lj.si \\ 3 National Veterinary Institute, Veterinary Faculty, University of Ljubljana, Gerbičeva 60, \\ 1115 Ljubljana, Slovenia; tomislav.paller@vf.uni-lj.si \\ * Correspondence: ivan.toplak@vf.uni-lj.si
}

check for updates

Citation: Jevšnik Virant, M.; Černe, D.; Petrovec, M.; Paller, T.; Toplak, I. Genetic Characterisation and Comparison of Three Human Coronaviruses (HKU1, OC43, 229E) from Patients and Bovine Coronavirus $(\mathrm{BCoV})$ from Cattle with Respiratory Disease in Slovenia. Viruses 2021, 13, 676. https://doi.org/10.3390/ v13040676

Academic Editor: Stefano Aquaro

Received: 24 March 2021

Accepted: 12 April 2021

Published: 15 April 2021

Publisher's Note: MDPI stays neutral with regard to jurisdictional claims in published maps and institutional affiliations.

Copyright: (c) 2021 by the authors. Licensee MDPI, Basel, Switzerland. This article is an open access article distributed under the terms and conditions of the Creative Commons Attribution (CC BY) license (https:// creativecommons.org/licenses/by/ $4.0 /)$.

\begin{abstract}
Coronaviruses (CoV) are widely distributed pathogens of human and animals and can cause mild or severe respiratory and gastrointestinal disease. Antigenic and genetic similarity of some CoVs within the Betacoronavirus genus is evident. Therefore, for the first time in Slovenia, we investigated the genetic diversity of partial 390-nucleotides of RNA-dependent-RNA polymerase gene (RdRp) for 66 human $(\mathrm{HCoV})$ and 24 bovine $\mathrm{CoV}(\mathrm{BCoV})$ positive samples, collected between 2010 and 2016 from human patients and cattle with respiratory disease. The characterized CoV strains belong to four different clusters, in three separate human clusters HCoV-HKU1 $(n=34), \mathrm{HCoV}-\mathrm{OC} 43$ $(n=31)$ and HCoV 229E $(n=1)$ and bovine grouping only as BCoVs $(n=24)$. BCoVs from cattle and $\mathrm{HCoV}-\mathrm{OC} 43$ were genetically the most closely related and share $96.4-97.1 \%$ nucleotide and 96.9-98.5\% amino acid identity.
\end{abstract}

Keywords: coronaviruses; genetic diversity; $\mathrm{HCoV}-\mathrm{OC} 43$; $\mathrm{BCoV}$; transmission

\section{Introduction}

Coronaviruses (CoVs) are widely distributed pathogens associated with respiratory and gastrointestinal diseases in humans and animals [1]. They are the largest enveloped single-strand RNA viruses and belong to the Coronaviridae family [2]. Based on the phylogenetic distances of highly conserved domains and according to the new International Committee for Taxonomy of Viruses (ICTV), CoVs are divided into four genera in the Orthocoronavirinae subfamily named Alphacoronaviruses (divided into 14 subgenera), Betacoronaviruses (divided into five subgenera), Deltacoronaviruses (divided into three subgenera) and Gammacoronaviruses (divided into three subgenera) [3-5].

The emergence of Severe Acute Respiratory Syndrome coronavirus (SARS-CoV) (Betacoronavirus genus, Sarbecovirus subgenus) in 2003, increased interest in hunting for novel CoVs. Before the first SARS epidemic, only two CoVs were described in humans: HCoV-229E (Alphacoronaviruses genus, Duvinacovirus subgenus) and HCoV-OC43 (Betacoronaviruses genus, Embecovirus subgenus, Betacoronavirus 1 species). Soon after the first SARS $\mathrm{CoV}$ epidemic, two additional human CoVs were described: HCoV-NL63 (Alphacoronavirus genus, Setracoronavirus subgenus) and HCoV-HKU1 (Betacoronavirus genus, Embecovirus subgenus). These newly discovered $\mathrm{HCoVs}$ mostly cause mild upper-respiratory-tract infections, and only in infants, immunocompromised patients; in elderly patients, CoVs can cause more severe respiratory disorders [6-8]. In 2012, a new CoV, Middle East Respiratory Syndrome coronavirus (MERS CoV) (Betacoronavirus genus, Merbecovirus subgenus), was 
discovered from patients with a mysterious, fatal disease. Both SARS-CoV and MERS-CoV cause severe respiratory diseases $[9,10]$ and are of zoonotic origin [11,12]. As a zoonotic threat, $\mathrm{CoV}$ implies the need to monitor $\mathrm{CoV}$ associated with domestic animals in contact with humans.

At the end of December 2019, several cases of human patients with viral pneumonia were reported in Wuhan, Hubei Province, People's Republic of China (PRC) and the novel SARS CoV-2 was discovered, producing fatal coronavirus disease (COVID-19) in around $2 \%$ of infected individuals and great public health concern [13]. From January 2020 to April 2021, SARS CoV-2 was spreading through human-to-human transmission throughout the world and producing the largest global pandemic in recent human history with more than one hundred million of infected people. Genetic analysis of the complete genome sequence of SARS CoV-2 revealed a $96.2 \%$ recognition rate with bat SARS coronavirus RaTG13 [14,15]. Similar to other coronaviruses, SARS CoV-2 has many potential natural hosts, intermediate hosts and final hosts.

Data regarding CoV infections before the SARS CoV-2 pandemic and strains circulating in Slovenia remain highly limited. From June 2007 to May 2008, 664 specimens were collected from 592 children under six years of age hospitalized at the University Children's Hospital in Ljubljana and sent for the routine laboratory detection of respiratory viruses. HCoV RNA was detected in 40 (6\%, 95\% CI: 4.3-8.1\%) of 664 samples. Of these specimens, $21 / 40$ (52.5\%) were identified as species HKU1, 7/40 (17.5\%) as OC43, 6/40 (15\%) as 229E, and $6 / 40(15 \%)$ as NL63 [16].

Bovine coronavirus $(\mathrm{BCoV})$ is inter-species transmissible, and $\mathrm{BCoV}$-like viruses have been detected in several ruminant species and humans. $\mathrm{BCoV}$ is distributed worldwide and is associated with neonatal calf diarrhea [17], winter dysentery in adult animals [18], and disorders in the respiratory tract [19]. All BCoV strains characterized from different geographic areas belong to the subgroup initially designated as 2a [20], and according to the new ICTV classification, BCoV belongs to the Betacoronavirus genus, genetically closely related to the HCoV-OC43 in Embecovirus subgenus and Betacoronavirus 1 species. Some previous publications indicated that approximately $90 \%$ of the worldwide cattle population has antibodies against $\mathrm{BCoV}$, and a survey on experimental interspecies transmission between wild ruminants, dogs, horses, and calves suggests the importance of BCoV investigation [21,22]. With whole-genome phylogenetic analysis, $83 \mathrm{BCoV}$ strains were classified into two major genotypes (European and American types); moreover, the European and American types were divided into eleven and three genotypes, respectively [23]. BCoV can significantly economically impact the veterinary industry [24], as other coronaviruses can in other animals $[25,26]$.

Nasal swab samples were collected in Slovenia between 2012 and 2014, from twentyeight herds from 133 affected live cattle that were clinically suffering from symptoms of respiratory disease, and $12.3 \%$ of the tested animals were detected as BCoV positive using the real-time PCR method, confirming the regular circulation of this virus in Slovenian cattle herds [27].

Within the Betacoronavirus genus, $\mathrm{BCoV}$ shares a global nucleotide identity of $96 \%$ with human coronavirus HCoV-OC43. Vijgen and co-workers demonstrated, using molecular clock analysis, that $\mathrm{HCoV}-\mathrm{OC} 43$ has a zoonotic origin and was transmitted from bovine to human around 1890 [28]. CoVs are unique among RNA viruses because of their replication and transcription mechanism; therefore, $\mathrm{CoVs}$ are characterized by a high potential of evolution, adaptation, and interspecies jumping [29]. HCoV-OC43 is the most common human coronavirus and has high genetic diversity. Five genotypes of HCoV-OC43 (A to E) have been identified, and Genotype D was dominant between 2004 and 2012 [30,31].

According to previously observed antigenic and genetic similarity, this study provides the first genetic comparison of $66 \mathrm{HCoVs}$ and $24 \mathrm{BCoV}$ circulating strains collected between 2010 and 2016 in Slovenia. 


\section{Materials and Methods}

\subsection{Clinical Specimens}

From 2010 to 2016, 16,732 human nasopharyngeal swab samples were collected from patients (female:male $=1: 1.14$ ) with acute respiratory tract infections and admitted to University Medical Centre Ljubljana. All nasopharyngeal swabs were sent to the laboratory of the Institute of Microbiology and Immunology for the routine detection of respiratory viruses. The study protocol was approved on 15 March 2016 for human samples by the National Medical Ethics Committee of the Republic of Slovenia (No. 0120-110/2016-2).

From 2010 to 2016, a total of 133 nasopharyngeal swabs from affected live cattle with respiratory illness and 84 from dead cattle with pneumonia were collected and included in the study. Live and dead cattle were from category between three-month- and one-year-old animals. Ethics approval for testing animal specimens was not needed since samples were primarily taken for routine diagnostic surveillance by the local veterinary specialists.

\subsection{Sample Preparation, Nucleic-Acid Extraction, and Real-Time RT-PCR}

Human nasopharyngeal swabs were collected using flocked-tip swabs and transported to the laboratory in a Copan universal transport medium (UTM-RT) system (Copan Italia, Brescia, Italy). Total nucleic acids were isolated from $190 \mu \mathrm{L}$ of each human nasopharyngeal swab using a total nucleic acid isolation kit on a MagNa Pure Compact instrument (Roche Applied Science, Mannheim, Germany), according to the manufacturer's instructions. An additional $5 \mu \mathrm{L}$ of Equine herpesvirus 1 and Equine arteritis virus isolates were added to all samples for external DNA and RNA control and were detected in separate duplex PCR reactions with other targets [32,33].

All four HCoVs (229E, OC43, NL63, and HKU1) and all other respiratory viruses, including respiratory syncytial virus (RSV), human rhinoviruses (HRV), human metapneumovirus (HMPV), human bocavirus ( $\mathrm{HBoV})$, adenoviruses (AdVs), parainfluenza viruses 1-3 (PIV 1-3), enterovirus (EV) and influenza viruses A and B (Flu A-B) were detected by using one-step real-time RT-PCR assay in a Step-One Real-Time PCR system (Applied Biosystems, Carlsbad, CA) [34-41]. A total $5 \mu \mathrm{L}$ of total nucleic acid was added to $15 \mu \mathrm{L}$ of reaction mixture including 2 X Reaction Mix, SuperScript ${ }^{\circledR}$ III RT/Platinum ${ }^{\circledR}$ TaqMix (Invitrogen, Carlsbad, CA, USA). The cycling conditions were universal for all tested respiratory viruses: $20 \mathrm{~min}$ at $50{ }^{\circ} \mathrm{C}, 2 \mathrm{~min}$ at $95^{\circ} \mathrm{C}$, and 45 cycles of $15 \mathrm{~s}$ at $95^{\circ} \mathrm{C}$ and $45 \mathrm{~s}$ at $60^{\circ} \mathrm{C}$.

From 133 affected live cattle (collected from 24 different cattle herds) with symptoms of respiratory disease, nasopharyngeal swab samples were collected into sterile swabs (Sigma Virocult ${ }^{\circledR}$, MW 951S, Leicester, UK). From 84 dead cattle with pneumonia and/or diarrhea originated from 76 different cattle herds, $10 \mathrm{~cm}^{3}$ lung tissue and/or feces samples were collected. About $1 \mathrm{~cm}^{3}$ of the samples was homogenized in dilution 1:10 in RPMI-1640 (Gibco, Life Technologies Inc., Grand Island, NY, USA) and stored at $<-15^{\circ} \mathrm{C}$ until testing. Total RNA was extracted from $140 \mu \mathrm{L}$ of homogenate using a commercial kit for RNA extraction (QIAamp ${ }^{\circledR}$ Viral RNA Mini Kit, Qiagen, Hilden, Germany) according to the manufacturer's instructions. Individual samples were tested using a commercial real-time PCR method, detecting specific nucleic acids of seven different respiratory pathogens, including the detection of endogenous internal positive control (IPC) for controlling the efficiency of extraction and the absence of inhibitors in individual samples. Samples were tested on a 96-tube microplate. On each microplate, the positive controls for all tested pathogens were included. A commercial TaqMan ${ }^{\circledR}$ real-time PCR kit for the detection of seven major ruminant pathogens (LSI VetMAX ${ }^{\mathrm{TM}}$ Screening Pack-Ruminants Respiratory Pathogens, LSI, Lissieu, France), which allows the simultaneous detection of the Micoplasma bovis, Histophilus somni, Pasteurella multocida, Mannheimia haemolytica, $\mathrm{BCoV}$, bovine respiratory syncytial virus (BRSV), and Bovine parainfluenza 3 (PI-3) was used as previously described [27]. The amplification was performed using an Mx3005P real-time PCR machine (Stratagene, San Diego, CA, USA). The fluorescent signal was detected after each annealing, and the results were presented as a cycle threshold value for individual samples. Analysis 
of real-time amplification curves was performed using commercial thermal cycler system software; to determine fluorescence baselines, an "auto baseline" was used.

\subsection{RT-PCR for Coronaviruses and DNA Sequencing}

From previously recognized $\mathrm{CoV}$ positive samples, a 440-bp-long fragment of the RNA dependent RNA polymerase $(R d R p)$ gene was amplified using the primers and protocol as described by Stephensen [42]. The RT-PCR was performed by using a One Step RT-PCR Kit (Qiagen, Holden, Germany). The amplified products were detected via agarose gel electrophoresis and sequenced by Sanger sequencing, as described in a previous publication [43].

\subsection{Data Analysis}

Nucleotide sequences, obtained from the RT-PCR products, were assembled using the DNASTAR software (version 5.05) and compared to the known sequences of the RdRp gene of coronaviruses from the GenBank database, using the Basic Local Alignment Search Tool (BLAST) program; 390-bp-long sequences were aligned using the ClustalW algorithm and with the reference sequences of $\mathrm{CoV}$ s from Genbank, including the most closely related sequences of $\mathrm{BCoVs}$ and $\mathrm{HCoVs}$. A maximum-likelihood phylogenetic tree was constructed on the GTR + G + I model using MEGA 6.06 software [43]. Genetic relationships among all the included CoVs were calculated with branch statistics using the bootstrap analysis of 1000 replicates.

\section{Results}

From a total of 16,732 tested human samples, 976 (5.8\%) were detected as HCoVpositive, and within CoV-positive samples, 523 (53.6\%) were negative for other human respiratory pathogens (RSV, HRV, HMPV, HCoVs, HBoV, AdV, PIV, EV, Flu A, and FluB), as tested with real-time RT-PCR methods. The median age of HCoVs-positive patients was 11 years (14 days to 99 years).

From 133 tested live cattle samples, 16 (12.0\%) were $\mathrm{CoV}$ positive, while from 84 dead cattle, $10(11.9 \%)$ samples were BCoV-positive by real-time RT-PCR, respectively. None of seven respiratory cattle pathogens (M. bovis, H. somni, P. multocida, M. haemolytica, $\mathrm{BCoV}$, BRSV and BPI-3) was detected in 30 (13.8\%) of the tested bovine clinical samples. The $\mathrm{BCoV}$ positive samples were detected in cattle from the age of three months up to one year.

To determine the overall genetic diversity, $66 \mathrm{HCoVs}$ and $24 \mathrm{BCoV}$ have been included in sequencing and phylogenetic analysis. A phylogenetic tree of a 390-bp fragment of the polymerase gene with only representative sequences was prepared, including available sequences from the GenBank database (Figure 1). The phylogenetic analysis shows that the determined Slovenian CoV strains from this study are classified into four different previously determined species, bovine grouping only as BCoVs $(n=24)$ and into human HCoV-HKU1 $(n=34)$, HCoV-OC43 $(n=31)$ and HCoV 229E $(n=1)$.

Thirty-four Slovenian HCoV-HKU1 belong to HKU1 with 97.2-100\% nucleotide identity to each other and were further divided into two lineages with $99.7-100 \%$ identity within each group and from $97.2-97.7 \%$ nucleotide identity between these two lineages. The first lineage, representing Slovenian HKU1/SLO-39995/2013, KX059693, has 100\% nucleotide identity with strain HCoV/KENYA/001/2010 (KP112150) and 28 other HKU1 sequences in GenBank from China and Australia. The second lineage, representing Slovenian HKU1/SLO/20580/2010, KX059667, has 100\% nucleotide identity to strain CU-H2238/2010 (JX513213) from Thailand and fifty other HKU1 sequences from China, USA and Brazil (Figure 1). 


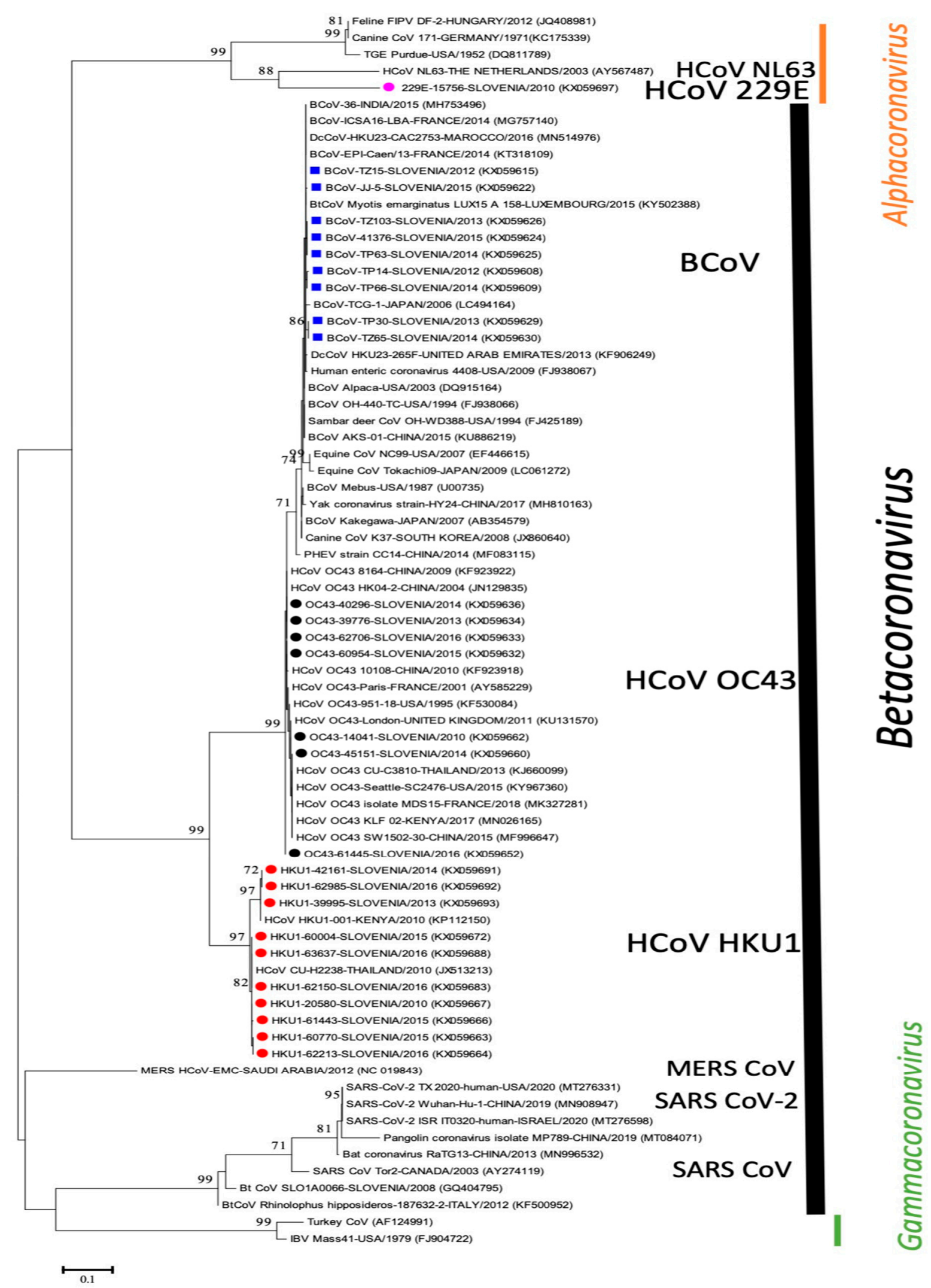

Figure 1. Phylogenetic tree based on 390-nucleotide-long sequences of RdRp gene with 9 representatives of Slovenian BCoV (ם) and 18 representatives of Slovenian HCoV: HCoV-OC43 (•), HCoV-HKU1 (•), HCoV-229E (•), including 46 CoVs from GenBank database (with name of CoV strains, country, and accession numbers). Bootstrap values below 70 are not shown. Phylogenetic tree shows only representative sequences from Slovenia while the identified 100\% identical sequences were not presented on tree because of graphical limits. 
Thirty-one Slovenian HCoV-OC43 belong to OC43 with $98.7-100 \%$ nucleotide identity and were further divided into three lineages with $98.7-99.2 \%$ nucleotide identity between them. The first lineage (representing Slovenian OC43/SLO/14041/2010, KX059662) has 100\% nucleotide identity to HCoV-OC43/UK/London/2011 strain (KU131570) and 18 other sequences in GenBank from France, USA and China. The second lineage (representing Slovenian OC43/SLO/60954/2015, KX059632) has a high nucleotide identity (99.74\%) to OC43/Seattle/USA/SC0776/2019 (MN310478) and to available OC43 strains from France, USA and China. Two strains (OC43/SLO/61445/2016, KX059652 and OC43/SLO/62519/2016, KX059653) form the third lineage separate from the other two lineages and are most closely related (99.74\%) to OC43/Seattle/USA/SC0776/2019 (MN310478) and several other strains from USA France and China (Figure 1).

From the determined $24 \mathrm{BCoV}$ sequences, 12 originated from live cattle with respiratory symptoms, 7 from dead animals with pneumonia and 5 from dead animals with diarrhea (Table S1). The sequenced 24 positive $\mathrm{BCoV}$ samples were collected from 18 different cattle herds, located in 15 different municipalities throughout Slovenia. BCoV were closely related to each other, with $99.2-100 \%$ nucleotide identity. The most closely related BCoV sequences from GenBank were FRA/EPI/Caen/2014 (KT318109) from France (100\%) and AKS-01 (KU886219) from China (99.7\%) and other CoV strains from different species (Figure 1). Human enteric coronavirus strain 4408 (FJ938067) and the identified Slovenian BCoV from this study share $99.7 \%$ nucleotide identity.

Determined BCoVs from cattle and $\mathrm{HCoV-OC43} \mathrm{share} \mathrm{96.4-97.1 \%} \mathrm{nucleotide} \mathrm{and}$ 96.9-98.5\% amino acid identity. The most closely related human and bovine sequences from this study are $\mathrm{HCoV}-\mathrm{OC} 43 / \mathrm{SLO} / 63863 / 2016$ and BCoV/SLO/5580/2013, which share $97.1 \%$ nucleotide identity. The HCoV-OC43 and HCoV-HKU1 were the most prevalent in the whole study period (from February 2010 to February 2016), with increasing numbers of detected HCoV-HKU1 strains in 2014, 2015, and 2016, while the highest number of HCoV-OC43 strains were identified in 2014 (Figure 2).

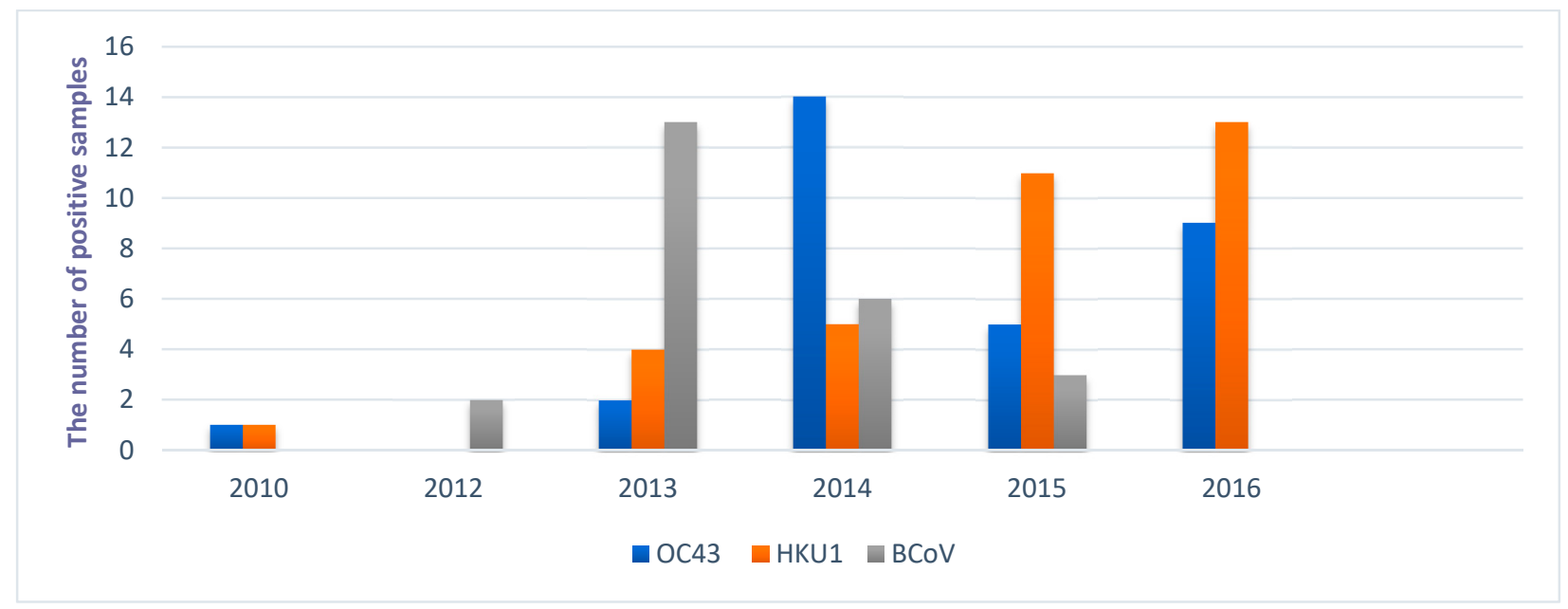

Figure 2. Yearly distribution of sequenced human coronavirus OC43 and HKU1 genotypes (HCoV-OC43 and HCoV-HKU1) and Bovine coronavirus (BCoV) in Slovenia during 2010 and 2016.

\section{Discussion}

This study is the first genetic comparison of CoVs circulating in Slovenian human and cattle populations and their phylogenetic relationship with CoVs available in GenBank database. A phylogenetic comparison of 390 nucleotides long sequences of RdRp gene showed that $\mathrm{BCoV}$ and $\mathrm{HCoV}$ were clearly separated from each other, and further CoVs differentiation is evident; one species represents $\mathrm{BCoV}$ only, and three other previously known species represent HCoV-OC43, HCoV-HKU1, and HCoV-NL63. The identified $\mathrm{BCoV}(n=24)$ and $\mathrm{HCoV}-\mathrm{OC} 43(n=31)$ share $96.4-97.1 \%$ nucleotide and $96.9-98.5 \%$ amino 
acid identity with each other, confirming a historically close relationship between BCoVs and HCoV-OC43, as described by Vijgen et al. [28]. Although Kin et al. demonstrated three sub-clusters within the BCoV cluster by using phylogenetic analysis of three genes (nsp12, $\mathrm{S}$ and $\mathrm{N}$ ) with longer sequences [44] than in our study, the comparison of 390 nucleotides long sequences of RdRp not allows further sub-clustering of $\mathrm{BCoV}$, as expected. Twentyfour BCoV sequences collected between 2012 and 2015 from 18 different cattle herds in this study were closely related to each other with $99.2 \%$ to $100 \%$ nucleotide identity confirming the identification of a genetically homogeneous group of $\mathrm{BCoV}$ in Slovenia, detected from live cattle with respiratory symptoms, dead animals with pneumonia, and dead animals with diarrhea. Nevertheless, even that rather small number of $\mathrm{BCoV}$ positive samples were sequenced, these $\mathrm{BCoV}$ positive samples were originated from fifteen different municipalities, which are from five of a total twelve different administrative regions in Slovenia. The results of this study thus represent important data about circulating field strains in cattle herds and the first genetic characterization of $\mathrm{BCoV}$ from our country. Within the Slovenian $\mathrm{BCoV}$ sequences, the closest published BCoV is FRA/EPI/Caen/2014 (KT318109) from France (100\% nucleotide identity) and AKS-01 (KU886219) from China (99.7\% nucleotide identity), confirming the identification of genetically identical or very similar $\mathrm{BCoV}$ strains than identified in some other countries worldwide. If more $\mathrm{BCoV}$ sequences on the RdRp gene would have been available also from other countries, the analysis could have been more precise also for this viral genome region.

In the whole study period, between February 2010 and February 2016, the detected $\mathrm{CoVs}$ from human and cattle patients were collected, with the highest observed prevalence in winter months, confirming strong seasonality for the detected positive samples as previously observed [45]. The genetic comparison of $66 \mathrm{HCoV}$ and $24 \mathrm{BCoV}$ from patients with clinical signs of respiratory disease did not provide evidence for zoonotic transmission of $\mathrm{BCoV}$ from bovine patients to humans in Slovenia. However, according to the close relationship between the $\mathrm{HCoV}$ and $\mathrm{BCoV}$ strains, we cannot completely exclude the possibility of interspecies transmission if only mild clinical symptoms are present in human patients because, in this case, patients will not be sampled and tested as in this study, in which only samples from patients with clear and severe respiratory signs or diarrhea were included. To better understand the epidemiology of closely related strains of $\mathrm{CoV}$, longer sequences with complete genomes or specific genes (nsp12, $\mathrm{S}$ and $\mathrm{N}$ ) will be needed from these archive samples and compared in a longer study period [14,15,23,44].

The previous study in Slovenia, with the testing of 592 samples of hospitalized children under six years, identified $40 \mathrm{HCoV}$ positive samples between 2007 and 2008, and four $\mathrm{HCoV}$ species were detected using the real-time PCR method, with the highest prevalence of HCoV-HKU1 (52.5\%), HCoV-OC43 (17.5\%), 229E (15\%) and NL63 (15\%) [46]. A similar distribution of $\mathrm{HCoV}$ was identified in this study by direct Sanger sequencing of a 390nt-long partial RdRp gene: HCoV-HKU1 (51.51\%), HCoV-OC43 (46.96\%), 229E (1.51\%), suggesting the circulation of genetically similar strains of $\mathrm{HCoV}$ in the human population for several years. The obtained total of 90 new sequences from Slovenia in this study is the first genetic comparison of data for circulating field $\mathrm{HCoV}$ and $\mathrm{BCoV}$, deposited in GenBank (KX059608-KX059697). As other researchers had assumed, we confirmed that the sequencing and phylogenetic analysis based on 390-nucleotide-long sequences of a single gene might not be sufficient to define the differences between genetically closely related strains, but this study confirmed that clear differentiation between different human, $\mathrm{BCoV}$ and other $\mathrm{CoV}$ is possible. This approach can be an important tool for the fast and reliable identification and characterization of genetically diverse CoVs, because the RdRp gene is a highly conserved region of the viral genome [30,47]. Although Lau et al. suggested that the more accurate phylogenetic analysis should be performed by amplification and sequencing of at least two gene loci, one from ORF1ab (e.g., RdRp or helicase) and one from HE to $\mathrm{N}$ (e.g., $\mathrm{S}$ or N) [30] this is not always possible for smaller laboratories. Sequencing of additional gene region was not done in our study, but genetic characterization of bovine 
and human CoV strains for differentiation of closely related strains from selected archive samples is still possible in further studies.

The whole seasons with sequenced CoV strains in our study were represented only in 2014 and 2015. In other years positive samples of CoV were included into sequencing because they were available in laboratory archive from routine testing. The observed high two-year dynamic for HCoV-OC43, which was the most prevalent $\mathrm{HCoV}$ in 2014 $(14 / 19,73.7 \%)$ and $\mathrm{HCoV}-\mathrm{HKU} 1$, which was most frequently detected $\mathrm{HCoV}$ in 2015 $(11 / 16,68.7 \%)$ showed needs for continuously sequencing of field strains of $\mathrm{CoV}$, also better understand the epidemiology of not highly virulent $\mathrm{HCoVs}$. The majority of $\mathrm{BCoV}$ positive cattle samples were identified within the determination of the prevalence of ten pathogens (one of these pathogens was $\mathrm{BCoV}$ ) detected by a real-time PCR method in live [27] and dead cattle with respiratory disease. Other $\mathrm{BCoV}$ positive samples were collected from individual detected positive cases, but rather low number of field samples are tested each year in cattle for this virus in our routine laboratories. Although positive samples of $\mathrm{HCoV}$ and $\mathrm{BCoV}$ were detected in all years of our study period, only limited of them were included further processed for sequencing. However, observations from this study provides also some important first data about circulation of $\mathrm{CoV}$ strains in human and cattle population in Slovenia and further studies are needed, based on more complete genome sequences and from a longer period of study.

The similarity between species within the Betacoronaviruses genus is high and, therefore, the interspecies transmission is a common phenomenon leading to the emergence of new pathogens, such as SARS-CoV and MERS-CoV [11,12]. Genetically closely related strains within the Betacoronavirus 1 species, including BCoV, PHEV, Canine respiratory coronavirus $(\mathrm{CRCoV})$ and $\mathrm{HCoV}-\mathrm{OC} 43$ and close contacts between animals and humans, also provides possibilities for adaptation to the human host which can lead to a new human coronavirus, as happened at the end of the 19th century with HCoV-OC43 [44]. The most closely related human and bovine sequences from this study are $\mathrm{HCoV}-\mathrm{OC} 43$ and $\mathrm{BCoV}$, which share 97.1\% nucleotide identity, both detected between 2013 and 2016. Due to CoV's characteristics and close human-to-animal contact, the continuous epidemiological and phylogenetic surveys are needed to understand the epidemiology of these two genetically closely related CoVs.

In conclusion, the genetic comparison of 90 field positive samples of $\mathrm{CoVs}$, circulating in Slovenian human and cattle populations, showed that 34 of them were grouped as $\mathrm{HCoV}$ HKU1, 31 as HCoV-OC43 and one as HCoV 229E, while all 24 cattle positive samples were grouping only as $\mathrm{BCoVs}$. The genetic comparison of determined strains of $\mathrm{BCoVs}$ and HCoV-OC43 revealed $96.4-97.1 \%$ nucleotide identity to each other, with clearly genetic differentiation between human and cattle $\mathrm{CoV}$ strains. Sequencing and phylogenetic analysis, based on 390-nucleotide-long sequences of RdRp gene, provide fast and reliable differentiation between different strains of $\mathrm{HCoV}, \mathrm{BCoV}$ and also other $\mathrm{CoV}$, but for better differentiation of genetically very closely related strains sequencing of additional virus genome region or sequencing of complete genome is needed. The result of this study provides the first genetic characterization of field $\mathrm{HCoV}$ and $\mathrm{BCoV}$ from Slovenia.

Supplementary Materials: The following are available online at https: / www.mdpi.com/article / 10.3390/v13040676/s1: Table S1: GenBank accession numbers associated with the sequences determined in this study.

Author Contributions: Conceptualization: M.J.V., M.P. and I.T.; sample collection organization: M.J.V. and T.P.; methodology and investigation: M.J.V., D.Č. and I.T.; formal analysis: I.T., D.Č. and T.P.; writing-original draft preparation: M.J.V. and I.T.; writing-review and editing: M.J.V., D.Č., M.P., T.P. and I.T.; founding acquisition: M.P., I.T. All authors have read and agreed to the published version of the manuscript.

Funding: This study was supported by the Slovenian Research Agency (Research Programme P3-0083 and P4-0092) and institutional department funds.

Institutional Review Board Statement: Not applicable. 
Informed Consent Statement: Not applicable.

Conflicts of Interest: The authors declare no conflict of interest. The funders had no role in the design of the study; in the collection, analyses, or interpretation of data; in the writing of the manuscript, or in the decision to publish the results.

\section{References}

1. Navas-Martin, S.; Weiss, S.R. SARS: Lessons Learned from Other Coronaviruses. Viral Immunol. 2003, 16, 461-474. [CrossRef] [PubMed]

2. Gorbalenya, A.E.; Enjuanes, L.; Ziebuhr, J.; Snijder, E.J. Nidovirales: Evolving the largest RNA virus genome. Virus Res. 2006, 117, 17-37. [CrossRef] [PubMed]

3. Adams, M.J.; Carstens, E.B. Ratification vote on taxonomic proposals to the International Committee on Taxonomy of Viruses (2012). Arch. Virol. 2012, 157, 1411-1422. [CrossRef] [PubMed]

4. Woo, P.C.; Lau, S.K.; Lam, C.S.; Lau, C.C.; Tsang, A.K.; Lau, J.H.; Bai, R.; Teng, J.L.; Tsang, C.C.; Wang, M.; et al. Discovery of Seven Novel Mammalian and Avian Coronaviruses in the Genus Deltacoronavirus Supports Bat Coronaviruses as the Gene Source of Alphacoronavirus and Betacoronavirus and Avian Coronaviruses as the Gene Source of Gammacoronavirus and Deltacoronavirus. J. Virol. 2012, 86, 3995-4008. [CrossRef]

5. ICTV Virus Taxonomy: 2019 Release. Available online: https://talk.ictvonline.org/ictv-reports/ictv_9th_report/positive-senserna-viruses-2011/w/posrna_viruses/223/coronaviridae-figures (accessed on 23 March 2021).

6. Garbino, J.; Crespo, S.; Aubert, J.D.; Rochat, T.; Ninet, B.; Deffernez, C.; Wunderli, W.; Pache, J.C.; Soccal, P.M.; Kaiser, L. A prospective hospital-based study of the clinical impact of non-severe acute respiratory syndrome (Non-SARS)-related human coronavirus infection. Clin. Infect. Dis. 2006, 43, 1009-1015. [CrossRef]

7. Esposito, S.; Bosis, S.; Niesters, H.G.; Tremolati, E.; Begliatti, E.; Rognoni, A.; Tagliabue, C.; Principi, N.; Osterhaus, A.D. Impact of human coronavirus infections in otherwise healthy children who attended an emergency department. J. Med. Virol. 2006, 78, 1609-1615. [CrossRef]

8. Principi, N.; Bosis, S.; Esposito, S. Effects of Coronavirus Infections in Children. Emerg. Infect. Dis. 2010, 16, 183-188. [CrossRef] [PubMed]

9. Peiris, J.S.; Guan, Y.; Yuen, K.Y. Severe acute respiratory syndrome. Nat. Med. 2004, 10, 88-97. [CrossRef] [PubMed]

10. Khan, G. A novel coronavirus capable of lethal human infections: An emerging picture. Virol. J. 2013, 10, 66. [CrossRef]

11. Li, W.; Shi, Z.; Yu, M.; Ren, W.; Smith, C.; Epstein, J.H.; Wang, H.; Crameri, G.; Hu, Z.; Zhang, H.; et al. Bats are natural reservoirs of SARS-like coronaviruses. Science 2005, 310, 676-679. [CrossRef] [PubMed]

12. Gossner, C.; Danielson, N.; Gervelmeyer, A.; Berthe, F.; Faye, B.; Kaasik Aaslav, K.; Adlhoch, C.; Zeller, H.; Penttinen, P.; Coulombier, D. Human-Dromedary Camel Interactions and the Risk of Acquiring Zoonotic Middle East Respiratory Syn-drome Coronavirus Infection. Zoonoses Public Health 2016, 63, 1-9. [CrossRef]

13. Huang, C.; Wang, Y.; Li, X.; Ren, L.; Zhao, J.; Hu, Y.; Zhang, L.; Fan, G.; Xu, J.; Gu, X.; et al. Clinical features of patients infected with 2019 novel coronavirus in Wuhan, China. Lancet 2020, 395, 497-506. [CrossRef]

14. Chen, N.; Zhou, M.; Dong, X.; Qu, J.; Gong, F.; Han, Y.; Qiu, Y.; Wang, J.; Liu, Y.; Wei, Y.; et al. Epidemiological and clinical characteristics of 99 cases of 2019 novel coronavirus pneumonia in Wuhan, China: A descriptive study. Lancet 2020, 395, 507-513. [CrossRef]

15. Zhou, P.; Yang, X.-L.; Wang, X.-G.; Hu, B.; Zhang, L.; Zhang, W.; Si, H.-R.; Zhu, Y.; Li, B.; Huang, C.-L.; et al. A pneumonia outbreak associated with a new coronavirus of probable bat origin. Nature 2020, 579, 270-273. [CrossRef] [PubMed]

16. Jevšnik, M.; Uršič, T.; Žigon, N.; Lusa, L.; Krivec, U.; Petrovec, M. Coronavirus infections in hospitalized pediatric patients with acute respiratory tract disease. BMC Infect. Dis. 2012, 12, 365. [CrossRef] [PubMed]

17. Mebus, C.A.; Stair, E.L.; Rhodes, M.B.; Twiehaus, M.J. Neonatal calf diarrhea: Propagation, attenuation, and characteristics of a coronavirus-like agent. Am. J. Veter. Res. 1973, 34, 145-150.

18. Saif, L.J.; Redman, D.R.; Brock, K.V.; Kohler, E.M.; Heckert, R.A. Winter dysentery in adult dairy cattle: Detection of coronavirus in the faeces. Veter. Rec. 1988, 123, 300-301. [CrossRef] [PubMed]

19. Cho, K.-O.; Hoet, A.E.; Loerch, S.C.; Wittum, T.E.; Saif, L.J. Evaluation of concurrent shedding of bovine coronavirus via the respiratory tract and enteric route in feedlot cattle. Am. J. Veter. Res. 2001, 62, 1436-1441. [CrossRef] [PubMed]

20. Hasoksuz, M.; Vlasova, A.; Saif, L.J. Detection of group 2a coronaviruses with emphasis on bovine and wild ruminant strains. Virus isolation and detection of antibody, antigen, and nucleic acid. Methods Mol. Biol. 2008, 454, 43-59.

21. Barros, I.N.; Silva, S.O.; Nogueira Neto, F.S.; Asano, K.M.; Souza, S.P.; Richtzenhain, L.J.; Brandao, P.E. A multigene approach for comparing genealogy of Betacoronavirus from cattle and horses. Sci. World J. 2013, 2013, 349702. [CrossRef] [PubMed]

22. Saif, L.J. Bovine Respiratory Coronavirus. Veter. Clin. N. Am. Food Anim. Pr. 2010, 26, 349-364. [CrossRef]

23. Suzuki, T.; Otake, Y.; Uchimoto, S.; Hasebe, A.; Goto, Y. Genomic Characterization and Phylogenetic Classification of Bovine Coronaviruses Through Whole Genome Sequence Analysis. Viruses 2020, 12, 183. [CrossRef]

24. Fulton, R.W.; Herd, H.R.; Sorensen, N.J.; Confer, A.W.; Ritchey, J.W.; Ridpath, J.F.; Burge, L.J. Enteric disease in postweaned beef calves associated with Bovine coronavirus clade 2. J. Veter. Diagn. Investig. 2015, 27, 97-101. [CrossRef] [PubMed]

25. Wang, L.; Byrum, B.; Zhang, Y. Porcine Coronavirus HKU15 Detected in 9 US States, 2014. Emerg. Infect. Dis. 2014, 20, 1594-1595. [CrossRef] 
26. Cavanagh, D. A nomenclature for avian coronavirus isolates and the question of species status. Avian Pathol. 2001, 30, 109-115. [CrossRef] [PubMed]

27. Paller, T.; Hostnik, P.; Pogačnik, M.; Toplak, I. The prevalence of ten pathogens detected by a real-time PCR method in nasal swab samples collected from live cattle with respiratory disease. Slov. Vet. Res. 2017, 54, 101-107.

28. Vijgen, L.; Keyaerts, E.; Moes, E.; Thoelen, I.; Wollants, E.; Lemey, P.; Vandamme, A.M.; Van Ranst, M. Complete genomic sequence of human coronavirus OC43: Molecular clock analysis suggests a relatively recent zoonotic coronavirus transmission event. J. Virol. 2005, 79, 1595-1604. [CrossRef] [PubMed]

29. Woo, P.C.Y.; Lau, S.K.P.; Huang, Y.; Yuen, K.-Y. Coronavirus Diversity, Phylogeny and Interspecies Jumping. Exp. Biol. Med. 2009, 234, 1117-1127. [CrossRef] [PubMed]

30. Lau, S.K.P.; Lee, P.; Tsang, A.K.L.; Yip, C.C.Y.; Tse, H.; Lee, R.A.; So, L.-Y.; Lau, Y.-L.; Chan, K.-H.; Woo, P.C.Y.; et al. Molecular Epidemiology of Human Coronavirus OC43 Reveals Evolution of Different Genotypes over Time and Recent Emergence of a Novel Genotype due to Natural Recombination. J. Virol. 2011, 85, 11325-11337. [CrossRef] [PubMed]

31. Zhang, Y.; Li, J.; Xiao, Y.; Zhang, J.; Wang, Y.; Chen, L.; Paranhos-Baccalà, G.; Ren, L.; Wang, J. Genotype shift in human coronavirus OC43 and emergence of a novel genotype by natural recombination. J. Infect. 2015, 70, 641-650. [CrossRef] [PubMed]

32. Diallo, I.S.; Hewitson, G.; Wright, L.; Rodwell, B.J.; Corney, B.G. Detection of equine herpesvirus type 1 using a real-time polymerase chain reaction. J. Virol. Methods 2006, 131, 92-98. [CrossRef]

33. Mankoč, S.; Hostnik, P.; Grom, J.; Toplak, I.; Klobučar, I.; Kosec, M.; Barlic-Maganja, D. Comparison of different molecular methods for assessment of equine arteritis virus (EAV) infection: A novel one-step MGB real-time RT-PCR assay, PCR-ELISA and classical RT-PCR for detection of highly diverse sequences of Slovenian EAV variants. J. Virol. Methods 2007, 146, 341-354. [CrossRef]

34. Kuypers, J.; Wright, N.; Morrow, R. Evaluation of quantitative and type-specific real-time RT-PCR assays for detection of respiratory syncytial virus in respiratory specimens from children. J. Clin. Virol. 2004, 31, 123-129. [CrossRef]

35. Kuypers, J.; Wright, N.; Ferrenberg, J.; Huang, M.-L.; Cent, A.; Corey, L.; Morrow, R. Comparison of Real-Time PCR Assays with Fluorescent-Antibody Assays for Diagnosis of Respiratory Virus Infections in Children. J. Clin. Microbiol. 2006, 44, 2382-2388. [CrossRef]

36. Daum, L.T.; Canas, L.C.; Arulanandam, B.P.; Niemeyer, D.; Valdes, J.J.; Chambers, J.P. Real-time RT-PCR assays for type and subtype detection of influenza A and B viruses. Influ. Other Respir. Viruses 2007, 1, 167-175. [CrossRef]

37. Maertzdorf, J.; Wang, C.K.; Brown, J.B.; Quinto, J.D.; Chu, M.; De Graaf, M.; Hoogen, B.G.V.D.; Spaete, R.; Osterhaus, A.D.M.E.; Fouchier, R.A.M. Real-Time Reverse Transcriptase PCR Assay for Detection of Human Metapneumoviruses from All Known Genetic Lineages. J. Clin. Microbiol. 2004, 42, 981-986. [CrossRef] [PubMed]

38. Lu, X.; Chittaganpitch, M.; Olsen, S.J.; Mackay, I.M.; Sloots, T.P.; Fry, A.M.; Erdman, D.D. Real-Time PCR Assays for Detection of Bocavirus in Human Specimens. J. Clin. Microbiol. 2006, 44, 3231-3235. [CrossRef] [PubMed]

39. De Vos, N.; Vankeerberghen, A.; Vaeyens, F.; Van Vaerenbergh, K.; Boel, A.; De Beenhouwer, H. Simultaneous detection of human bocavirus and adenovirus by multiplex real-time PCR in a Belgian paediatric population. Eur. J. Clin. Microbiol. Infect. Dis. 2009, 28, 1305-1310. [CrossRef] [PubMed]

40. Scheltinga, S.; Templeton, K.; Beersma, M.; Claas, E. Diagnosis of human metapneumovirus and rhinovirus in patients with respiratory tract infections by an internally controlled multiplex real-time RNA PCR. J. Clin. Virol. 2005, 33, 306-311. [CrossRef]

41. Kuypers, J.; Martin, E.T.; Heugel, J.; Wright, N.; Morrow, R.; Englund, J.A. Clinical Disease in Children Associated with Newly Described Coronavirus Subtypes. Pediatrics 2007, 119, e70-e76. [CrossRef]

42. Stephensen, C.B.; Casebolt, D.B.; Gangopadhyay, N.N. Phylogenetic analysis of a highly conserved region of the polymerase gene from 11 coronaviruses and development of a consensus polymerase chain reaction assay. Virus Res. 1999, 60, 181-189. [CrossRef]

43. Rihtarič, D.; Hostnik, P.; Steyer, A.; Grom, J.; Toplak, I. Identification of SARS-like coronaviruses in horseshoe bats (Rhinolophus hipposideros) in Slovenia. Arch. Virol. 2010, 155, 507-514. [CrossRef]

44. Kin, N.; Miszczak, F.; Diancourt, L.; Caro, V.; Moutou, F.; Vabret, A.; Gouilh, M.A. Comparative molecular epidemiology of two closely related coronaviruses, bovine coronavirus (BCoV) and human coronavirus OC43 (HCoV-OC43), reveals a different evolutionary pattern. Infect. Genet. Evol. 2016, 40, 186-191. [CrossRef] [PubMed]

45. Beaudeau, F.; Björkman, C.; Alenius, S.; Frössling, J. Spatial patterns of Bovine Corona Virus and Bovine Respiratory Syncytial Virus in the Swedish beef cattle population. Acta Veter. Scand. 2010, 52, 33. [CrossRef] [PubMed]

46. Jevšnik, M.; Steyer, A.; Pokorn, M.; Mrvič, T.; Grosek, Š.; Strle, F.; Lusa, L.; Petrovec, M. The Role of Human Coronaviruses in Children Hospitalized for Acute Bronchiolitis, Acute Gastroenteritis, and Febrile Seizures: A 2-Year Prospective Study. PLoS ONE 2016, 11, e0155555. [CrossRef]

47. Woo, P.C.Y.; Lau, S.K.P.; Yip, C.C.Y.; Huang, Y.; Tsoi, H.-W.; Chan, K.-H.; Yuen, K.-Y. Comparative Analysis of 22 Coronavirus HKU1 Genomes Reveals a Novel Genotype and Evidence of Natural Recombination in Coronavirus HKU1. J. Virol. 2006, 80, 7136-7145. [CrossRef] [PubMed] 